\title{
What are the similarities between stress, sudden cardiac death in Gallus gallus and sudden unexpected death in people with epilepsy
}

\author{
Fulvio A. Scorza', Ricardo de Albuquerque², \\ Ricardo M. Arida ${ }^{3}$, Marly de Albuquerque', \\ Vera C. Terra ${ }^{4}$, Hélio R. Machado ${ }^{4}$, Roberta M. Cysneiros 5 , \\ Carla A. Scorza', Esper A. Cavalheiro'
}

\begin{abstract}
Individuals with epilepsy are at higher risk of sudden unexpected death in epilepsy (SUDEP), responsible for $7.5 \%$ to $17 \%$ of all deaths in epilepsy. Many factors are current associated with SUDEP and possible effect of stress and cardiac arrhythmia are still not clear. Sudden death syndrome (SDS) in chickens is a disease characterized by an acute death of wellnourished and seeming healthy Gallus gallus after abrupt and brief flapping of their wings, similar to an epileptic seizure, with an incidence estimated as 0.5 to $5 \%$ in broiler chickens. A variety of nutritional and environmental factors have been included: but the exactly etiology of SDS is unknown. Studies had suggested that the hearts of broiler chickens are considerably more susceptible to arrhythmias and stress may induce ventricular arrhythmia and thus, sudden cardiac death. In this way, SDS in Gallus gallus could be an interesting model to study SUDEP.
\end{abstract}

Key words: sudden cardiac death, epilepsy, Gallus gallus.

Similaridades entre stress, morte súbita cardíaca na espécie Gallus gallus e morte súbita em epilepsia

\section{RESUMO}

Indivíduos com epilepsia têm maior risco de sofrer morte súbita e inexplicada em epilepsia (SUDEP), responsável por 7,5\% a 17\% de todas as mortes em epilepsia. Diversos fatores têm sido associados com SUDEP e um possível efeito do stress e das arritmias cardíacas ainda não é claro. A síndrome da morte súbita (SDS) em galinhas é uma situação caracterizada por uma morte aguda em Gallus gallus bem nutridos e aparentemente saudáveis após um evento curto e abrupto de bater de asas, semelhante a uma crise epiléptica, com incidência de 0,5 a 5\% em granjas. Uma ampla variedade de fatores nutricionais e ambientais tem sido considerada, mas a causa exata da SDS é desconhecida. Estudos têm sugerido que o coração das galinhas criadas em granjas é mais sensível a arritmias cardíacas e que o stress poderia levar a arritmias cardíacas e, portanto, a morte súbita cardíaca. Assim, SDS

Correspondence Fulvio Alexandre Scorza Rua Botucatu 862 04023-900 São Paulo SP - Brasil E-mail: scorza.nexp@epm.br em Gallus gallus pode ser considerado um interessante modelo de SUDEP.

Palavras-chave: morte súbita cardiac, epilepsia, Gallus gallus. 


\section{Similarities 1: General aspects of sudden unexpected death in people with epilepsy and sudden death syndrome in Gallus gallus}

Individuals with epilepsy are at higher risk of death than the general population and sudden unexpected death in epilepsy (SUDEP) is the most important direct epilepsy-related cause of death ${ }^{1}$. SUDEP is responsible for $7.5 \%$ to $17 \%$ of all deaths in epilepsy and has an incidence among adults between 1:500 and 1:1,000 patientyears ${ }^{2}$. A number of associated factors for SUDEP have been reported but the results are not wholly consistent between studies. These include refractoriness of the epilepsy, presence of generalized tonic-clonic seizures, polytherapy with antiepileptic drugs (AEDs), young age, duration of the seizure disorder ranging from 15 to 20 years, early onset of epilepsy and winter temperatures ${ }^{1,3}$. Additionally, potential mechanisms for SUDEP is unknown, but it is very probable that cardiac arrhythmia during and between seizures play a potential role ${ }^{1}$.

Sudden death syndrome (SDS) is a disease characterized by an acute death of well-nourished and seeming healthy Gallus gallus after abrupt and brief flapping of their wings ${ }^{4-7}$. The incidence of SDS has been estimated as 0.5 to $5 \%$ in broiler chickens (Gallus gallus) and represents a major economic loss to the broiler industry ${ }^{7-8}$. Information concerning risk factors for SDS is difficult, but a variety of nutritional and environmental factors have been included: lighting, B vitamins, pelleting of feed, fats in diet and growth rate ${ }^{9,10}$. The exactly etiology of SDS is unknown; however, SDS has been suggested to be a cardiac disease ${ }^{7}$. For instance, several elegant studies from Olkowski group have been concluded that the hearts of broiler chickens are considerably more susceptible to arrhythmias, which could be direct involved in the pathogenesis of $\operatorname{SDS}^{10,11}$.

Based on these very stimulating similarities, our research group recently purposed that SDS in Gallus gallus could be an interesting model to study SUDEP ${ }^{11}$. In brief, it was demonstrated that SDS chickens exhibited a sudden attack prior to death lasting an average of 53 $\mathrm{s}$ and characterized by loss of balance, violent flapping, and strong muscular contractions ${ }^{12}$, which is very similar with complex partial seizures in rats and in mice previously described by our group, an experimental approach that may serve as a model of epilepsy mimicking the human condition ${ }^{13,14}$.

\section{Similarities 2: Stress, sudden unexpected death in people with epilepsy and sudden death syndrome in Gallus gallus}

As related before, some risk factors for sudden cardiac death in epilepsy have been proposed, but no single risk factor is common to all cases, suggesting multiple mechanisms or trigger factors. Based on this, we believe that is interesting to explore the relevance of stress as a potential causal factor of SUDEP in patients with chronic uncontrolled epilepsy. To date, there is still no generally accepted consensus on the definition of stress, however, the majority of studies define stress as circumstances that people would find stressful ${ }^{15}$.

It has been demonstrated that a diagnosis of epilepsy may bring with it many potential stresses, many of which are chronic ${ }^{15}$. It is also clear that the unpredictability of continuing seizures, the embarrassment of having seizures, the stigma of having epilepsy, health concerns over side effects of antiepileptic drugs (AEDs), education and employment difficulties, and social isolation all contribute to the chronic stress experienced by patients with epilepsy ${ }^{15}$. Furthermore, experimental and human studies have also demonstrated that acute and chronic stress is able to increase seizure susceptibility ${ }^{16}$. Following these reasoning, as SUDEP is mainly a problem for patients with chronic uncontrolled epilepsy ${ }^{1,17}$, it is very reasonable to think that stress may also be a factor in SUDEP occurrence.

Concerning Gallus gallus, the history is not different. Studies with different species of laboratory animals suggest that stress may induce ventricular arrhythmia and sudden cardiac death ${ }^{18-20}$. Concerning Prof. Olkowski ${ }^{18}$, one of the most important researcher on studies about SDS in Gallus gallus, the potential role of stress in the etiology of ventricular arrhythmia and SDS could be point in the following angle: in a commercial setting, chickens are frequently exposed to various forms of environmental stress (e.g., overcrowding, antagonistic behavior), metabolic stress associated with rapid growth, or physically induced stress associated with procedural activities $^{18}$. On many occasions during various research trials, Olkowski and colleagues ${ }^{18}$ observed increased incidence of SDS when chickens were subjected to some stressful activities such as blood collection, weighing, or during routine catching, loading and transportation ${ }^{18}$. Based on this, the researchers formulated the hypothesis that the increased susceptibility of the myocardium to arrhythmia in some chickens is associated with specific patho-physiological changes in the myocardium resulting from metabolic strain, with a high risk of acute heart failure when further compromised by stress ${ }^{18}$.

\section{Final comments}

Investigators and research staff should be familiar with the normal behavior of the species and recognize abnormal behaviors, once that different animal species are sensitive to the presence of stress in their environment. In general lines, several studies provide clear and convincing evidence that stress can also result in histo- 
pathological changes in the heart, whereas genetically determined and/or acquired dysfunction of the transmitter systems may interact to predispose to arrhythmias and sudden cardiac death ${ }^{21}$.

Finally, while admitting the deficiencies in our current knowledge about the exact mechanism of SUDEP and SDS in Gallus gallus, the order of the day is: No stress please!

\section{REFERENCES}

1. Stollberger C, Finsterer J. Cardiorespiratory findings in sudden unexplained/unexpected death in epilepsy (SUDEP). Epilepsy Res 2004;59:51-60.

2. Schuele SU, Widdess-Walsh P, Bermeo A, Lüders HO. Sudden unexplained death in epilepsy: the role of the heart. Cleve Clin J Med 2007;74(Suppl): s121-127.

3. Scorza FA, de Albuquerque M, Arida RM, Cavalheiro EA. Sudden unexpected death in epilepsy: are winter temperatures a new potential risk factor? Epilepsy Behav 2007;10:509-510.

4. Ononiwu JC, Thomson RG, Carlson HC, Julian RJ. Pathological studies of "sudden death syndrome" in broiler chickens. Can Vet J 1979;20:70-73.

5. Hulan HW, Proudfoot FG, McRae KB. Effect of vitamins on the incidence of mortality and acute death syndrome ("flip-over") in broiler chickens. Poult Sci 1980;59:927-931.

6. Steele P, Edgar J, Doncon G. Effect of biotin supplementation on incidence of acute death syndrome in broiler chickens. Poult Sci 1982;61:909-913.

7. Imaeda N. Characterization of serum enzyme activities and electrolyte levels in broiler chickens after death from sudden death syndrome. Poult Sci 1999;78:66-69.

8. Summers JD, Bedford M, Spratt D. Sudden death syndrome. Is it a metabolic disease? Feedstuffs 19807;59:20.
9. Nain S, Laarveld B, Wojnarowicz C, Olkowski AA. Excessive dietary vitamin D supplementation as a risk factor for sudden death syndrome in fast growing commercial broilers. Comp Biochem Physiol A Mol Integr Physiol 2007;148:828-833.

10. Olkowski AA. Pathophysiology of heart failure in broiler chickens: structural, biochemical, and molecular characteristics. Poult Sci 2007;86:999-1005.

11. Scorza FA, de Albuquerque R, Arida RM, et al. Could sudden death syndrome (SDS) in chickens (Gallus gallus) be a valid animal model for sudden unexpected death in epilepsy (SUDEP)? Medical Hypotheses 2009:73:67-69.

12. Newberry RC, Gardiner EE, Hunt JR. Behavior of chickens prior to death from sudden death syndrome. Poult Sci 1987;66:1446-1450.

13. Colugnati DB, Gomes PA, Arida RM, et al. Analysis of cardiac parameters in animals with epilepsy: possible cause of sudden death? Arq Neuropsiquiatr 2005;63:1035-1041.

14. Cavalheiro EA. The pilocarpine model of epilepsy. Ital J Neurol Sci 1995;16: 33-37.

15. Yuen AW, Thompson PJ, Flugel D, Bell GS, Sander JW. Mortality and morbidity rates are increased in people with epilepsy: is stress part of the equation? Epilepsy Behav 2007;10:1-7

16. Rhodes ME, Harney JP, Frye CA. Gonadal, adrenal, and neuroactive steroids' role in ictal activity. Brain Res 2004;1000:8-18.

17. Tomson T, Nashef L, Ryvlin P. Sudden unexpected death in epilepsy: current knowledge and future directions. Lancet Neurol 2008;7:1021-1031.

18. Olkowski AA, Wojnarowicz C, Nain S, Ling B, Alcorn JM, Laarveld B. A study on pathogenesis of sudden death syndrome in broiler chickens. Res Vet Sci 2008;85:131-140.

19. Rubart M, Zipes DP. Mechanisms of sudden cardiac death. J Clin Invest 2005; 115:2305-2315

20. Sgoifo A, Koolhaas J, De Boer S, et al. Social stress, autonomic neural activation, and cardiac activity in rats. Neurosci Biobehav Rev 1999;23:915-923.

21. Lathers CM, Schraeder PL. Stress and sudden death. Epilepsy Behav 2006; 9:236-242. 